\title{
Pengaruh Likuiditas, Risiko Bisnis dan Struktur Aktiva terhadap Struktur Modal
}

(Studi empiris pada perusahaan manfukatur sektor industri barang konsumsi yang terdaftar di Bursa Efek Indonesia pada periode 2015-2019)

\section{Afa $^{1}$, Shadrina Hazmi ${ }^{1 *}$}

Fakultas Ekonomi dan Bisnis, Universitas Mercu Buana Yogyakarta, Indonesia

*Corresponding author: shadrina@mercubuana-yogya.ac.id
Article history

Received, 05 March 2021

Revised 1, 22 April 2021

Revised 2, 16 July 2021 Accepted, 26 July 2021

\section{Abstract}

The aim of this study was to find out the effect of liquidity, business risk, and asset structure to capital structure in consumer goods industry manufacturing companies listed on the Bursa Efek Indonesia for the period 2015-2019. The ratio used to measure the liquidity variable is the current ratio, the business risk variable is measured by BRISK, and the asset structure variable is measured by the fixed asset ratio. The sampling technique used was purposive sampling method. This research was conducted with 19 samples of companies in the consumer goods industry sector. The results show that the liquidity variable has a significant effect on the capital structure of manufacturing companies in the consumer goods industry sector listed on the BEI for the period 20152019, meanwhile, the business risk and asset structure variables have no significant effect on the capital structure of manufacturing companies in the consumer goods industry listed on the BEI for the period 2015-2019

Keyword: Liquidity (Current Ratio), Business Risk (BRISK), Asset Structure (Fixed Asset Ratio / FAR), and Capital Structure (Debt to Equity Ratio / DER).

\section{Abstrak}

Penelitian ini bertujuan untuk mengetahui pengaruh likuiditas, risiko bisnis, dan struktur aktiva terhadap struktur modal pada perusahaan manufaktur sektor industri barang konsumsi yang terdaftar di BEI periode 2015 - 2019. Rasio yang digunakan untuk mengukur variabel likuiditas adalah current ratio, variabel risiko bisnis diukur dengan BRISK, dan variabel struktur aktiva diukur dengan fixed asset ratio. Teknik pengambilan sampel yang dilakukan yakni dengan menggunakan metode purposive sampling. Penelitian ini dilakukan dengan 19 sampel perusahaan sektor industri barang konsumsi. Hasil penelitian menunjukan bahwa variabel likuiditas berpengaruh signifikan terhadap struktur modal pada perusahaan manufaktur sektor industri barang konsumsi yang terdaftar di BEI periode 2015-2019, sedangkan untuk variabel risiko bisnis dan struktur aktiva tidak berpengaruh signifikan terhadap struktur modal pada perusahaan manufaktur sektor industri barang konsumsi yang terdaftar di BEI periode 2015-2019.

Kata kunci: Likuiditas (Current Ratio), Risiko Bisnis (BRISK), Struktur Aktiva (Fixed Asset Ratio/FAR), dan Struktur Modal (Debt to Equity Ratio/DER).

Cite this article:

Afa., Hazmi, Shadrina,. (2021). Pengaruh Likuiditas, Risiko Bisnis dan Struktur Aktiva terhadap Struktur Modal, Jurnal Al-Qardh, 6(1), 30-44. https://doi.org/ 10.23971/jaq.v6i1.2691

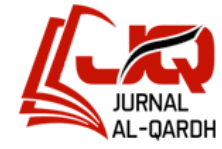

pISSN: $2354-6034$

eISSN: 2599 - 0187 


\section{Pendahuluan}

Struktur modal adalah perbandingan atau imbangan pendanaan jangka panjang perusahaan yang ditunjukkan oleh perbandingan hutang jangka panjang terhadap modal sendiri ${ }^{1}$. Struktur modal menjadi salah satu permasalahan yang paling penting dalam kesejahteraan keuangan perusahaan, karena dari pengadaan struktur modal itu sendiri hasil yang didapatkan nantinya akan mempunyai efek terhadap posisi keuangan perusahaan. Struktur modal yang optimal adalah struktur modal yang diperkirakan akan menghasilkan biaya modal rata-rata tertimbang yang paling rendah sehingga akan memaksimumkan nilai perusahaan ${ }^{2}$. Struktur modal dalam penelitian ini dapat diukur dengan debt to equity ratio (DER).

Adapun beberapa faktor yang mempengaruhi struktur modal bahwa ada beberapa faktor yang berpengaruh terhadap struktur modal dalam pengambilan keputusan antara lain: risiko bisnis, likuiditas, profitabilitas, struktur aset, kepemilikan manajerial, pertumbuhan aset, dan ukuran perusahaan ${ }^{3}$. Likuiditas merupakan salah satu rasio atau faktor yang mempengaruhi strukutur modal. Likuiditas merupakan kemampuan perusahaan untuk membayar kemampuan finansial jangka pendek tepat pada waktunya, likuiditas perusahaan ditujukan oleh besar kecilnya aktiva lancar yaitu aktiva yang mudah untuk diubah menjadi kas yang meliputi kas, surat berharga, piutang dan persediaan ${ }^{4}$

Likuiditas dalam penelitian ini di ukur dengan menggunakan Current Ratio yang merupakan perbandingan antara aktiva lancar dan hutang lancar. Menurut penelitian menyatakan bahwa likuiditas berpengaruh positif dan signifikan terhadap struktur modal dimana semakin tinggi likuiditas maka semakin tinggi struktur modal ${ }^{5}$. Hal ini dikarenakan, Semakin tinggi likuiditas perusahaan maka semakin tinggi kemampuan perusahaan dalam memenuhi kewajiban jangka pendeknya maka hal tersebut dapat mengindikasikan perusahaan berada dalam keadaan sehat ${ }^{6}$. Sedangkan dari hasil penelitian yang dilakukan oleh Deviani dan Sudjarni menyatakan bahwa Likuiditas memiliki pengaruh negatif dan signifikan terhadap struktur modal ${ }^{7}$.

Menurut Munandar, dkk risiko bisnis adalah ketidakpastian yang melekat dalam proyeksi tingkat pengembalian aktiva masa depan. Dalam perusahaan risiko bisnis akan meningkat jika menggunakan hutang yang tinggi. Hal ini juga akan meningkatkan kemungkinan kebangkrutan. Sebaiknya, jika suatu perusahaan tidak ingin mengalami kebangrutan maka suatu

\footnotetext{
1 Primantara, A., \& Dewi, M. (2016). Pengaruh Likuditas, Profitabilitas, Risiko Bisnis, Ukuran Perusahaan, dan Pajak Terhadap Struktur Modal. E-Jurnal Manajemen Unud, 2698-2699.

${ }^{2}$ Septiani, N., \& Suaryana, I. (2018). Pengaruh Profitabilitas, Ukuran Perusahaan, Struktur Aset, Risiko Bisnis dan Likuiditas pada Struktur Modal. E-Jurnal Akuntansi Universitas Udayana, Vol.22.3. Hal. 1648,1707.

${ }^{3}$ Putri, R. P., \& Andayani. (2018). Faktor-Faktor Yang Mempengaruhi Struktur Modal Perusahaan Manufaktur Di Bursa Efek Indonesia. Jurnal Ilmu dan Riset Akuntansi, Hal. 2.

${ }^{4}$ Primantara, A., \& Dewi, M, op. Cit.

${ }^{5}$ Primantara, A., \& Dewi, M, op. Cit.

${ }^{6}$ Seftianne, \& Handayani, R. (2011). Faktor-Faktor Yang Mempengaruhi Strukur Modal Pada Perusahaan Publik Sektor Manufaktur. Jurnal Bisnis dan Akuntansi, Vol.13, No,1, Hal.52.

${ }^{7}$ Deviani, M., \& Sudjarni, L. (2018). Pengaruh Tingkat Pertumbuhan, Struktur Aktiva, Profitabilitas,Dan Likuditas Terhadap Struktur Profitabilitas, Dan Likuiditas Terhadap Struktur. E-Jurnal Manajemen Unud, Vol. 7 , No. 3, Hal. 1244- 1246.
} 
perusahaan seharusnya menggunakan hutang yang rendah ${ }^{8}$. Risiko perusahaan yang tinggi pada umumnya lebih mengutamakan pendanaan internal daripada penggunaan hutang maupun penerbitan saham. Risiko bisnis dalam penelitian ini diukur dengan menggunakan BRISK yang merupakan perbandingan antara standar deviasi EBIT dengan aktiva tetap. Primantara dan Dewi dalam penelitiannya menyatakan bahwa risiko bisnis memiliki pengaruh negatif dan signifikan terhadap struktur modal dimana semakin tinggi risiko bisnis maka semakin rendah struktur modalnya9. Sedangkan dari hasil penelitian yang dilakukan oleh Nurwandari dan Hidayat menyatakan bahwa resiko bisnis berpengaruh positif signifikan terhadap struktur modal ${ }^{10}$.

Affandi menyatakan bahwa struktur aktiva atau Tangibility merupakan aset tetap yang penting dalam pendanaan perusahaan karena sebagai penyedia jaminan bagi pihak kreditur ${ }^{11}$. Sehingga, Menurut Brigham dan Houston "Perusahaan yang asetnya memadai untuk digunakan sebagai jaminan pinjaman cenderung akan cukup banyak menggunakan utang"12. Dengan begitu, jika suatu perusahaan cukup banyak menggunakan utang maka jumlah asset tangibility perusahaan akan memberikan pengaruh pada keputusan struktur modal perusahaan. Struktur aktiva dalam penelitian ini diukur dengan menggunakan fixed asset ratio/FAR. Penelitian yang dilakukan oleh Septiani dan Suaryana menyatakan bahwa struktur aktiva berpengaruh negatif terhadap struktur modal ${ }^{13}$. Sedangkan hasil penelitian dari Rubiyana dan Kristanti menyatakan bahwa struktur aktiva mampu mempengaruhi struktur modal secara positif ${ }^{14}$. Namun, Riyanto (dalam Riasita) menyatakan bahwa perusahaan yang sebagian besar modalnya tertanam dalam aset tetap akan mengutamakan pemenuhan modalnya dari modal yang permanen, yaitu modal sendiri sedangkan utang sifatnya hanya sebagai pelengkap. Dengan demikian, semakin tinggi struktur aset, maka penggunaan modal sendiri akan semakin tinggi atau dengan kata lain struktur modalnya akan semakin rendah.

Berdasarkan penjelasan latar belakang dan perbedaan hasil penelitian sebelumnya diatas maka peneliti tertarik untuk melakukan sebuah penelitian dengan judul pengaruh likuiditas, risiko bisnis, dan struktur aktiva terhadap struktur modal (Studi empiris pada perusahaan manufaktur sektor industri barang konsumsi yang terdaftar di Bursa Efek Indonesia (BEI) pada periode 2015 - 2019).

\footnotetext{
${ }^{8}$ Munandar, A., Pratiwi, A., \& Hasan, I. (2019). Pengaruh Risiko Bisnis Terhadap Struktur Modal Pada Perusahaan Pabrik Kertas PT. TJIWI KIMIA TBK PERIODE 2013-2018. Jurnal Manajemen dan Keuangan, Volume: 7 No: 2, Hal. 56.

${ }^{9}$ Primantara, A., \& Dewi, M, op. Cit.

${ }^{10}$ Nurwandari, N., \& Hidayat, I. (2017). Pengaruh Profitabilitas Dan Risiko Bisnis Terhadap Struktur Modal Perusahaan Food And Beverage. Jurnal Ilmu dan Riset Manajemen, Volume 6, Nomor 6, Hal. 12.

11 Affandi, R. D. (2016). Pengaruh Profitabilitas, Growth Opportunities, Likuiditas, Dan Tangibility Terhadap Struktur Modal Pada Perusahaan Sektor Infrastruktur, Utilitas, Dan Transportasi Yang Terdaftar Di Bursa Efek Indonesia Periode 2011-2014. Jurnal Ilmu Manajemen, Hal.174.

12 Ibid

${ }^{13}$ Septiani dan Suaryana, op. cit.

${ }^{14}$ Rubiyana, M., \& Kristanti. (2020). Pengaruh Profitabilitas, Struktur Aktiva, Pertumbuhan Perusahaan, Risiko Bisnis dan Aktivitas Perusahaan terhadap Struktur Modal. Balance: Economic, Business, Management, and Accounting Journal Vol. XVII No. 2 |Bulan Juli Tahun 2020.
} 


\section{Metode Penelitian \\ Populasi dan Sampel}

Populasi dalam penelitian ini adalah perusahaan manufaktur sektor industri barang konsumsi yang terdaftar di Bursa Efek Indonesia periode 2015 - 2019. Teknik sampel yang digunakan dalam penelitian ini ialah diambil berdasarkan purposive sampling yaitu pengambilan sampel yang didasarkan atas kriteria - kriteria atau karateristik tertentu. Kriteria - kriteria atau karakteristik yang diperlukan untuk pengambilan sampel ialah sebagai berikut:

1. Perusahaan manufaktur sektor industri barang konsumsi yang terdaftar secara berturut - turut di Bursa Efek Indonesia (BEI) periode 2015 - 2019.

2. Perusahaan manufaktur sektor industri barang konsumsi yang mempublikasikan laporan keuangan secara berturut - turut selama 5 tahun berturut - turut di BEI, yaitu periode $2015-2019$.

3. Perusahaan manufaktur sektor industri barang konsumsi yang memiliki data lengkap sesuai kebutuhan.

\section{Definisi Operasional Variabel}

Penelitian ini menggunakan variabel independen yaitu rasio likuiditas, risiko bisnis, dan struktur aktiva. Dan variabel dependennya yaitu struktur modal yang dirumuskan sebagai berikut:

\begin{tabular}{|c|c|}
\hline Variabel Penelitian & Proksi \\
\hline Likuiditas & Current Ratio $=\frac{\text { Aset Lancar }}{\text { Hutang Lancar }} \times 100 \%$ \\
\hline Risiko Bisnis & BRISK $=\frac{\text { oEBIT }}{\text { Total } \text { Aset }} \times 100 \%$ \\
\hline Struktur Aktiva & FAR $=\frac{\text { Total Aktiva Tetap }}{\text { Total Aktiva }} \times 100 \%$ \\
\hline Struktur Modal & Debt to Equity Ratio $=\frac{\text { Total Hutang }}{\text { Total Ekuitas }} \times 100 \%$ \\
\hline
\end{tabular}

Penelitian ini data dianalisis menggunakan analisis linier berganda dengan beberapa model pengujian sebagai berikut:

$$
\mathrm{DER}=\alpha+\beta 1 \mathrm{CR}+\beta 2 \mathrm{BRISK}+\beta 3 \mathrm{FAR}+e
$$

DER : Debt to Equity Ratio (Struktur Modal)

CR : Current Ratio (Likuiditas)

BRISK : Bussines Risk (Risiko Bisnis)

FAR : Fixed Asset Ratio (Struktur Aktiva)

\section{Tinjauan Pustaka}

Menurut Ryanto, struktur modal adalah pembelanjaan perusahaan yang tetap, dimana mencerminkan keseimbangan antara hutang jangka panjang dengan modal sendiri. Modigliani dan Merton Miller (MM), pada tahun 1958, ketika Profesor Franco Modigliani dan Merton Miller (selanjutnya disebut MM) menerbitkan apa yang disebut sebagai artikel keuangan paling berpengaruh yang pernah ditulis. MM membuktikan dengan menggunakan sekumpulan asumsi yang patut dipertanyakan, bahwa nilai suatu perusahaan seharusnya tidak dipengaruhi oleh struktur modalnya. Pecking Order Teory, teori ini menjelaskan mengapa perusahaan akan menentukan hirarki sumber dana yang paling disukai. Sesuai dengan teori ini maka perusahaan 
cenderung lebih memilih investasi akan dibiayai dengan dana internal terlebih dahulu (yaitu laba yang ditahan) untuk meningkatkan modal mereka, kemudian baru setelah itu perusahaan akan melirik ke pendanaan modal eksternal yang diikuti oleh penerbitan hutang baru, dan ketika perusahaan memerlukan dana yang lebih baru barulah akhirnya dilakukan dengan penerbitan ekuitas baru sebagai alternatif terakhir. Dan yang terakhir teori Trade-Off, Teori struktur modal MM mendapat tanggapan dan kritik dari berbagai pihak. Kritik paling relevan adalah mengenai biaya kesulitan keuangan (financial distress) akibat meningkatnya hutang. Perusahaan yang terus menambah hutang akan membayar bunga yang semakin besar dan kemungkingan penurunan laba bersih semakin besar. Hal ini dapat membawa perusahaan pada kondisi kesulitan keuangan yang akibatnya dapat menimbulkan biaya kesulitan keuangan dan berpotensi menuju kebangkrutan sehingga pada akhirnya menimbulkan biaya kebangkrutan. Teori trade-off menyatakan bahwa perusahaan berusaha menyeimbangkan antara keuntungan dari berkurangnya pajak karena adanya bunga hutang dengan biaya kesulitan keuangan karena tingginya proporsi hutang. Teori ini tidak dapat menjelaskan mengapa banyak perusahaan yang sukses memiliki hutang sedikit. Masalah - masalah yang terkait dengan kebangkrutan lebih mungkin timbul apabila perusahaan memiliki lebih banyak hutang dalam struktur modalnya. Dengan demikian, biaya kebangkrutan dapat menyebabkan perusahaan menahan diri dari penggunaan hutang yang berlebihan.

Likuiditas adalah kemampuan yang dimiliki perusahaan untuk memenuhi kewajiban finansialnya dalam jangka pendek dengan dana lancar yang tersedia, seperti membayar gaji, membayar hutang jangka pendek dan membayar biaya operasional ${ }^{15}$. Pengukuran likuiditas dilakukan dengan menggunakan current ratio. Current ratio merupakan perbandingan antara aset lancar (current asset) dengan hutang lancar (current liabilities). Menurut Joni dan Lina, Risiko bisnis merupakan salah satu risiko yang akan dihadapi perusahaan ketika menjalankan kegiatan operasinya, yaitu kemungkinan ketidakmampuan perusahaan untuk mendanai kegiatan operasinya $^{16}$. Pengukuran risiko bisnis dilakukan dengan menggunakan BRISK. BRISK merupakan perbandingan antara standar deviasi laba bersih sesudah bunga pajak (EBIT) dengan total asset dapat dilihat dari neraca dan laporan laba rugi perusahaan.

Struktur aktiva merupakan cerminan dari dua komponen aset tetap secara garis besar dalam komposisinya yaitu aset lancar dan aset tetap. Pengukuran struktur aktiva dilakukan dengan menggunakan fixed asset ratio/FAR. fixed asset ratio/FAR mengetahui seberapa besar porsi aktiva tetap yang dapat dijadikan perusahaan sebagai jaminan atas pinjaman yang dilakukannya dan diukur dengan satuan $\%$.

\section{Pengaruh Likuiditas Terhadap Struktur Modal}

Likuiditas adalah Rasio likuiditas yang digunakan untuk mengukur kemampuan perusahaan untuk memenuhi kewajiban jangka pendeknya (Van Horne dan Wachowicz,). Berdasarkan pecking order theory, tingkat likuiditas yang tinggi akan cenderung menahan

\footnotetext{
${ }^{15}$ Dewi, N., \& Badjra, I. (2014). Pengaruh Likuiditas, Profitabilitas, Tangibility Asset, Ukuran Perusahaan Dan Pajak Terhadap Asset, Ukuran Perusahaan Dan Pajak Terhadap. E-jurnal Manajemen, 3021.

${ }^{16}$ Wardhana, I., \& Sudiartha, G. (2015). Pengaruh Likuiditas, Ukuran Perusahaan, Risiko Bisnis, dan Usia Perusahaan Terhadap Struktur Modal Pada Industri Pariwisata Di Bursa Efek Indonesia Periode 2010-2013. EJurnal Manajemen Unud, Vol.4, N0.6, Hal.1704.
} 
perusahaan untuk menggunakan hutang karena perusahaan yang memiliki likuiditas yang tinggi berarti memiliki dana internal yang tinggi sehingga perusahaan tersebut akan mengutamakan penggunaan dana internal, daripada menggunakan dana eksternal, yang berarti bahwa dari sisi pecking order theory perusahaan cenderung lebih menyukai pendanaan internal. Alasannya karena dapat dipastikan kecilnya risiko yang akan ditanggung oleh perusahaan apabila menggunakan pendanaan internal. Perusahaan yang mempunyai likuiditas tinggi berarti mempunyai kemampuan membayar hutang jangka pendek, sehingga cenderung akan menurunkan total hutang, yang akhirnya struktur modal akan menjadi lebih kecil.

H1: Likuiditas berpengaruh negatif terhadap Struktur Modal.

\section{Pengaruh Risiko Bisnis Terhadap Struktur Modal}

Risiko bisnis adalah risiko yang ditimbulkan karena kegiatan operasional perusahaan sebagai akibat dari ketidakpastian pendapatan operasi dan laba sebelum bunga dan pajak. Suatu perusahaan dinilai menghadapi risiko bisnis jika ia menghasilkan laba yang berfluktuasi antara satu periode dengan periode, lain Joni dan Lina ${ }^{17}$. Hal ini juga akan meningkatkan kemungkinan kebangkrutan. Pendapat tersebut sesuai dengan trade - off theory yang menjelaskan bahwa penggunaan utang yang berlebihan, dapat dipastikan semakin meningkat pula risiko yang akan ditanggung oleh perusahaan sehingga terjadi kemungkinan kebangkrutan.

H2: Risiko Bisnis berpengaruh negatif terhadap struktur modal.

\section{Pengaruh Struktur Aktiva Terhadap Struktur Modal.}

Struktur aktiva merupakan penentuan seberapa besar jumlah alokasi untuk masingmasing komponen aktiva, baik aktiva tetap maupun aktiva lancar. Perusahaan yang memiliki perbandingan aktiva tetap yang lebih tinggi akan cenderung menggunakan utang lebih banyak karena aktiva tetap yang ada dapat digunakan sebagai jaminan utang. Weston dan Copeland menyatakan bahwa "perusahaan yang mempunyai aktiva tetap jangka panjang lebih besar, maka perusahaan tersebut akan banyak menggunakan hutang jangka panjang, dengan harapan aktiva tersebut dapat digunakan untuk menutup tagihannya"18. Oleh karena itu jumlah aktiva tetap yang semakin tinggi maka perusahaan lebih percaya diri dan mudah mendapatkan pendanaan yang bersumber dari hutang.

H3: Struktur Aktiva berpengaruh positif terhadap struktur modal.

\section{Pengaruh Likuditas, Risiko Bisnis, dan Struktur Aset Terhadap Struktur Modal.}

Pada dasarnya, suatu perusahaan tentu memiliki tujuan yang ingin dicapai suatu saat nantinya. Namun, untuk dapat mencapai tujuan tersebut perusahaan juga harus cepat dan tangap dalam menanggapi situasi serta kondisi yang akan terjadi suatu saat nantinya. Setiap perusahaan tentunya memiliki jumlah penerimaan serta pendapatan yang berbeda dalam memprioritaskan pembangunannya. Untuk meningkatkan kinerja perusahaan, pastinya setiap perusahaan membutuhkan modal, modal merupakan salah satu faktor yang dibutuhkan dalam kelangsungsan dan menjamin operasi perusahaan selain sumber material maupun faktor

${ }^{17}$ Munandar, A., Pratiwi, A., \& Hasan, I, op. cit.

${ }^{18}$ Maryanti , E. (2016). Analisis Profitabilitas, Pertumbuhan Perusahaan, Pertumbuhan Penjualan Dan Struktur Aktiva Terhadap Struktur Modal Pada Perusahaan Sektor Industri Barang Konsumsi. 
pendukung lainnya. suatu keputusan yang diambil manajer dalam pembelanjaan harus dipertimbangkan secara teiliti, sifat, dan biaya dari sumber dana yang akan dipilih karena masing - masing sumber dana tersebut memiliki konsuekensi finansial yang berbeda apalagi jika perusahaan tersebut akan melakukan ekspansi, pastinya membutuhkan modal yang tidak sedikit.

Berdasarkan Pecking off theory menyatakan bahwasannya suatu pemilik perusahaan cenderung lebih mengutamakan dana internal dibandingkan dana eksternal, karena menurut pihak perusahaan dengan menggunaan dana internal cenderung perusahaan akan sedikit megalami risiko usaha. Hal ini mengindikasikan bahwasannya perilaku kegiatan dalam memperoleh modal berkaitan juga dengan ketiga faktor yang dapat mempengaruhi struktur modal yakni Likuiditas, Risiko Bisnis, dan Struktur Aktiva, ketiga variabel tersebut diyakini dapat mempengaruhi struktul modal karena dari ketiga varaiebl tersebut berguna untuk melihat tingkat likuiditas di suatu perusahaan dalam memenuhi kewajibannya, risiko bisnis yang mungkin akan dialami oleh suatu perusaahan pada suatu hari nanti, serta melihat seberapa banyak kekayaan atau sumber - sumber atau struktur aset yang dimiliki oleh suatu perusahaan untuk dapat di jadikan jaminan utang. Berdasarkan penjelasan diatas serta hasil yang didukung oleh penelitian sebelumnya, maka bahwa dalam penelitian ini bertujuan untuk menguji pengaruh likuiditas, risiko bisnis, dan struktur aktiva terhadap struktur modal. Sehingga hipotesis ke empat yang diambil yaitu:

H4 : Likuiditas, Risiko Bisnis, dan Struktur Aktiva berpengaruh secara simultan terhadap struktur modal (studi empiris pada perusahaan manufaktur sektor industri konsumsi yang terdaftar di BEI periode 2015 - 2019).

\section{Hasil Penelitian}

pada penelitian ini populasi yang digunakan yaitu salah satu sektor perusahaan manufaktur yang terdaftar di BEI yakni sektor industri barang konsumsi yang terdaftar di Bursa Efek Indonesia (BEI) pada periode 2015 - 2019. Dan berdasarkan kriteria pemilihan sampel diperoleh sampel sebanyak 95 data.

Berikut dipaparkan hasil statistik deskriptif, sebagai berikut:

Tabel. 4.2 Hasil Uji statistik deskriptif

\begin{tabular}{|c|c|c|c|c|c|}
\hline & $\mathrm{N}$ & Minimum & Maximum & Mean & $\begin{array}{c}\text { Std. } \\
\text { Deviation }\end{array}$ \\
\hline Current Ratio & 95 & .10 & 9.28 & 2.8037 & 2.21892 \\
BRISK & 95 & .00 & .63 & .0904 & .12242 \\
FAR & 95 & .00 & 5.52 & .4989 & .71724 \\
DER & 95 & -2.13 & 2.65 & .7934 & .72497 \\
$\begin{array}{c}\text { Valid N } \\
\text { (listwise) }\end{array}$ & 95 & & & & \\
\hline
\end{tabular}

Sumber: Data Sekunder, diolah 2020

Berdasarkan tabel 4.2 diatas yang menunjukan gambaran secara umum statistik deskriptif variabel dependen dan variabel independen. Dapat diketahui bahwa pada variabel 
dependen struktur modal yang diukur dengan DER memiliki nilai minimun sebesar -2,13 pada perusahaan PT. Tiga Pilar Sejahtera Food, Tbk tahun 2019 dan nilai maximum sebesar 2,65 terletak pada perusahaan PT. Hanjaya Mandala Sampoerna, Tbk pada tahun 2017. Sedangkan nilai rata - rata yang diperoleh yaitu 0,7934 dan nilai standar deviasi nya sebesar 0,72497.

variable independen yaitu likuditas yang diukur dengan current ratio memiliki nilai minimun sebesar 0,10 terdapat pada perusahaan PT. Budi Strach \& Sweetener, Tbk tahun 2016 dan yang memiliki nilai maximun sebesar 9,28 terdapat pada perusahaan PT. Industri Jamu Dan Farmasi Sido Muncul, Tbk. tahun 2015. Sehingga, memiliki nilai rata - ratanya sebesar 2,8037 dan memiliki standar deviasi dengan nilai sebesar 2,21892. Risiko bisnis yang diukur dengan BRISK memiliki nilai minimun yaitu 0,00 yakni terdapat pada perusahaan PT. Budi Strach \& Sweetener, Tbk tahun 2015 - 2017 dan yang memiliki nilai maximun sebesar 0,63 terdapat pada perusahaan PT. Delta Djakarta, Tbk tahun 2016. Sehingga, memiliki nilai rata - ratanya sebesar 0,0904 dan memiliki standar deviasi dengan nilai sebesar 0,12242. Struktur aktiva yang diukur dengan FAR memiliki nilai minimun yaitu 0,00 yakni terdapat pada perusahaan PT. DaryaVaria Laboratoria, Tbk tahun 2015 dan yang memiliki nilai maximun sebesar 5,52 terdapat pada perusahaan PT. Budi Strach \& Sweetener, Tbk tahun 2018. Sehingga, memiliki nilai rata ratanya sebesar 0,4989 dan memiliki standar deviasi dengan nilai sebesar 0,71724.

\section{Uji Hipotesis}

Hipotesis dalam penelitian ini terbagi menjadi empat yaitu hipotesis pertama menyatakan bahwa likuiditas yang diukur dengan current ratio berpengaruh negatif terhadap struktur modal yang diukur dengan DER. Hipotesis kedua menyatakan bahwa risiko bisnis yang diukur dengan BRISK berpengaruh negatif terhadap struktur modal (DER). Hipotesis ketiga menyatakan bahwa struktur aktiva yang diukur dengan Fixed Asset Ratio berpengaruh positif terhadap struktur modal (DER). Dan hipotesis yang ke empat menyatakan bahwa likuiditas, risiko bisnis, dan struktur aktiva berpengaruh secara simultan terhadap struktur modal. Berikut hasil regresi untuk keempat hipotesis tersebut:

Tabel 4.3. Hasil Uji Regresi

\begin{tabular}{|l|c|}
\hline \multicolumn{1}{|c|}{ Variabel independen } & $\begin{array}{c}\text { Variabel dependen } \\
\text { Struktur Modal (DER) }\end{array}$ \\
\hline Konstanta & 0,328 \\
\hline Likuiditas (CR) & $-0,122$ \\
& 0,002 \\
\hline \multirow{2}{*}{ Risiko Bisnis (BRISK) } & 1,568 \\
& 0,576 \\
\hline \multirow{2}{*}{ Struktur Aktiva ( FAR) } & $-0,330$ \\
\hline Uji F & 0,415 \\
\hline R Square & 0,024 \\
\hline
\end{tabular}

Berdasarkan tabel 4.3, ditunjukan hasil koefisien regresi dari variabel likuiditas sebesar $-0,122$. Artinya variabel likuiditas yang diproksikan dengan current ratio berpengaruh negatif terhadap struktur modal sehingga jika variabel likuiditas meningkat sebesar satu satuan maka 
struktur modal akan mengalami penurunan sebesar 0,122 satuan dengan anggapan variabel independen lainnya tetap. Koefisien regresi risiko bisnis menyatakan hasil sebesar 1,568. Artinya variabel risiko bisnis yang diukur dengan BRISK berpengaruh positif terhadap struktur modal, sehingga jika variabel Risiko Bisnis meningkat sebesar satu satuan maka struktur modal akan mengalami kenaikan sebesar 1,568 satuan dengan anggapan variabel independen lainnya tetap. Koefisien regresi struktur aktiva menyatakan hasil sebesar -0,330. Artinya variabel struktur aktiva yang diproksikan dengan Fixed Asset Ratio (FAR) berpengaruh negatif terhadap struktur modal, sehingga jika variabel Struktur Aktiva meningkat sebesar satu satuan maka struktur modal akan mengalami penurunan sebesar 0,330 satuan dengan anggapan variabel independen lainnya tetap.

Nilai uji F sebesar 0,024 artinya bahwa variabel independen secara bersama - sama berpengauh secara simultan signifikan terhadap variabel dependen. dan nilai R Square sebesar 1,896 artinya hal ini menunjukkan variabel independent mempengaruhi variabel dependen sebesar 36,8\%, sedangkan 63,2\% dipengaruhi oleh variabel lain di luar penelitian ini. Berdasarkan penjelasan diatas maka dapat disimpulkan bahwa hipotesis pertama didukung, hipotesis kedua tidak terdukung, hipotesis ketiga tidak terdukung, dan hipotesis ke empat didukung.

\section{Pembahasan}

\section{Pengaruh Likuditas Terhadap Struktur Modal}

Berdasarkan tabel hasil uji t yang dilakukan menyatakan bahwa variabel likuiditas yang diukur dengan current ratio terhadap struktur modal yang diukur dengan DER, didapatkan kesimpulan bahwa likuditas berpengaruh signifikan terhadap struktur modal. Hal tersebut dikarenakan secara parsial nilai signifikannya diperoleh sebesar 0,002, menyatakan bahwa nilai signifikan yang diperoleh lebih kecil dari taraf signifikan yang telah ditentukan yaitu 0,05 $(0,002<0,05)$. Dengan demikian hipotesis yang didapatkan yaitu $\mathrm{H}_{0}$ ditolak dan $\mathrm{H}_{1}$ diterima. Artinya apabila semakin tinggi likuiditas suatu perusahaan maka semakin besar kemampuan perusahaan tersebut untuk membayar kewajiban jangka pendeknya atau dalam kata lain apabila suatu perusahaan memiliki likuiditas yang tinggi cenderung perusahaan tersebut tidak menggunakan hutang karena perusahaan memiliki dana internal yang besar. Likuiditas merupakan kemampuan yang dimiliki perusahaan untuk memenuhi kewajiban finansialnya dalam jangka pendek dengan dana lancar yang tersedia, seperti membayar gaji, membayar hutang jangka pendek dan membayar biaya operasional ${ }^{19}$. Hal ini juga sesuai dengan teori dari pecking off - theory yang menyatakan bahwa perusahaan cenderung lebih menyukai pendanaan internal. Karena dapat dipastikan kecilnya risiko yang akan ditanggung perusahaan apabila menggunakan pendanaan internal. Hal ini didukung oleh hasil penelitian yang dilakukan oleh Dewi dan Badjra $^{20}$, dan Hardanti dan Gunawan ${ }^{21}$ yang menyatakan bahwa likuditas berpengaruh negatif dan signifikan terhadap struktur modal. Hal ini berbeda dengan hasil

${ }^{19}$ Dewi, N., \& Badjra, I, op. cit.

${ }^{20}$ Dewi, N., \& Badjra, I, op. cit.

21 Hardanti, S., \& Gunawan, B. (2010). Pengaruh Size, Likuiditas, Profitabilitas, Risiko, Dan Pertumbuhan Penjualan Terhadap Struktur Modal (studi empiris pada perusahaan manufaktur di Bursa Efek Indonesia). Jurnal Akuntansi dan Investasi, Vol. 11 No. 2, Hal. 157 - 159. 
penelitian yang dilakukan oleh Dewiningrat dan Mustanda $^{22}$, Septiani dan Suaryana ${ }^{23}$, dan Zulkarnian $^{24}$ yang menyatakan bahwa likuiditas berpengaruh negatif dan tidak signifikan terhadap struktur modal.

\section{Pengaruh Risiko Bisnis Terhadap Struktur Modal}

Berdasarkan tabel hasil uji t yang dilakukan menyatakan bahwa variabel risiko bisnis yang diukur dengan BRISK terhadap struktur modal yang diukur dengan DER, didapatkan kesimpulan bahwa risiko bisnis tidak berpengaruh terhadap struktur modal. Hal tersebut dikarenakan berdasarkan pengujian hipotesis secara parsial nilai signifikan sebesar 0,576, menyatakan bahwa nilai signifikan yang diperoleh lebih besar dari taraf signifikan yang telah ditentukan yaitu $0,05(0,576>0,05)$. Dengan demikian, hipotesis yang didapatkan ialah $\mathrm{H} 0$ diterima dan Ha ditolak. Hasil penelitian tersebut artinya bahwa dari data perusahaan sampel yang digunakan pada periode 2015 -2019 bahwa besar kecilnya risiko bisnis yang dialami oleh suatu perusahaan tidak mempengaruhi struktur modalnya, karena perusahaan yang tingkat risiko tinggi belum tentu lebih menyukai pendanaan internal daripada eksternal begitupun sebaliknya. Risiko bisnis merupakan risiko yang ditimbulkan karena kegiatan operasional perusahaan sebagai akibat dari ketidakpastian pendapatan operasi dan laba sebelum bunga dan pajak. Risiko perusahaan yang tinggi pada umumnya lebih mengutamakan pendanaan internal daripada penggunaan hutang maupun penerbitan saham. Hal ini karena, semakin rendah risiko bisnis suatu perusahaan, maka semakin tinggi rasio utang optimalnya, sebaliknya. Hal tersebut juga harus disesuaikan dengan kondisi perusahaan yang dihadapkan pada suatu keputusan yang mengharuskan perusahaan untuk menggunakan hutang. Dan salah satu penyebab risiko bisnis tidak berpengaruh terhadap struktur modal dikarenakan terdapat beberapa investor atau kreditur yang memiliki sifat risk taker sehingga tidak terlalu memperhatikan risiko bisnis suatu perusahaan. Hasil penelitian ini sejalan dengan hasil penelitian yang dilakukan oleh Rubiyana dan Kristianti (2020) ${ }^{25}$, Hardanti dan Gunawan (2010) ${ }^{26}$, dan Septiani dan Suaryana (2018) ${ }^{27}$ menemukan hasil bahwa risiko bisnis tidak berpengaruh terhadap struktur modal. Sedangkan berdasarkan hasil penelitian yang dilakukan oleh Wairooy (2019) ${ }^{28}$ menemukan bahwa Risiko bisnis berpengaruh positif dan signifikan terhadap struktur modal pada perusahaan industri otomotif yang terdaftar di bursa efek Indonesia, artinya ketika risiko bisnis meningkat maka struktur modal akan meningkat.

\section{Pengaruh Struktur Aktiva Terhadap Struktur Modal}

Berdasarkan tabel hasil uji t yang dilakukan menyatakan bahwa variabel struktur aktiva yang diukur dengan FAR terhadap struktur modal yang diukur dengan DER, didapatkan kesimpulan bahwa struktur aktiva tidak berpengaruh terhadap struktur modal. Karena secara

\footnotetext{
${ }^{22}$ Dewiningrat, A. I., \& Mustanda, I. (2018). Pengaruh Likuiditas, Profitabilitas, Pertumbuhan Penjualan, Dan Struktur Aset Terhadap Struktur Modal. E-Jurnal Manajemen Unud, Vol. 7, Hal. 3476.

${ }^{23}$ Septiani dan Suaryana, op. cit.

${ }^{24}$ Zulkarnain, M. (2020). Pengaruh likuiditas dan profitabilitas terhadap struktur modal. Forum Ekonomi, Hal.52-54.

${ }^{25}$ Rubiyana, M., \& Kristanti, op. cit.

${ }^{26}$ Hardanti dan Gunawan, op. cit.

${ }^{27}$ Septiani dan Suaryana, op. cit.

${ }^{28}$ Wairooy, M. (2019). Pengaruh Ukuran Perusahaan dan Risiko Bisnis terhadap Struktur Modal Pada Perusahaan Industri Otomotif Yang Terdaftar Di Bursa Efek Indonesia. jurnal ekonomi, 79-89.
} 
parsial nilai signifikan yang diperolah sebesar 0,415 , menyatakan bahwa nilai signifikan yang diperoleh lebih besar dari taraf signifikan yang telah ditentukan yaitu $0,05(0,415>0,05)$.

Dengan demikian, maka hipotesis H0 diterima dan H3 ditolak. Hasil penelitian tersebut artinya bahwa sesuai dengan data perusahaan yang menjadi sampel, bahwa data struktur aktiva cenderung kecil sehingga tidak semua perusahaan dari sektor barang konsumsi pada periode 2015 - 2019 akan menggunakan aktivanya untuk jaminan hutang dan dalam pengambilan keputusan struktur modal tidak terlalu mempertimbangkan struktur aktivanya. Struktur aktiva merupakan kekayaan atau sumber-sumber ekonomi yang dimiliki oleh perusahaan yang diharapkan dapat memberikan manfaat bagi perusahaan dikemudian hari, dan merupakan penentu seberapa besar alokasi untuk masing- masing komponen aktiva. Hasil penelitian ini sejalan dengan hasil penelitian yang dilakuakan oleh Seftianne dan Handayani ${ }^{29}$, Nabayu, dkk ${ }^{30}$ yang menyatakan bahwa struktur aktiva tidak berpengaruh terhadap struktur modal. Hal ini berbeda dengan hasil penelitian yang dilakukan oleh Putrid an Fadhila ${ }^{31}$, Affandi ${ }^{32}$, Mulyani ${ }^{33}$, Tijow, $\mathrm{dkk}^{34}$, Rubiyana dan Kristianti ${ }^{35}$ yang menyatakan struktur aktiva berpengaruh positif terhadap struktur modal yang menyatakan bahwa semakin besar struktur aktiva perusahaan, maka stuktur modal perusahaan yang berasal dari hutang akan semakin meningkat.

\section{Pengaruh Likuditas, Risiko Bisnis, dan Struktur Aset Terhadap Struktur Modal.}

Pada dasarnya untuk menguji apakah seluruh variabel independen yang digunakan dalam penelitian ini memiliki pengaruh secara simultan terhadap variabel dependen para peneliti umumnya cenderung sering menggunakan pengujian simultan atau uji F. Sehingga pada penelitian ini peneliti juga melakukan hal yang sama yakni menguji secara keseluruhan variabel independen terhadap variabel dependen dengan menggunakan pengujian Uji $\mathrm{F}$ atau simultan untuk dapat mengetahui apakah seluruh variabel independen berpengaruh secara simultan terhadap variabel dependen. Berdasarkan hasil uji $\mathrm{F}$ pada tabel. 13 dapat diketahui bahwa nilai F diperoleh sebesar 3,346 dan tingkat nilai signifikan yang diperoleh dari seluruh variabel independen yaitu sebesar 0,024. Yang artinya jika dilihat dari $F_{\text {hitung }}$ nya yaitu 3,346 $>F_{\text {tabel }} 2,75$. Dan dilihat dari nilai signifikan dari seluruh variabel independennya $0,024<0,05$. Artinya dapat ditarik kesimpulan bahwa variabel independen secara bersama - sama berpengauh secara simultan signifikan terhadap variabel dependen. Dan Berdasarkan tabel.14 Menunjukan hasil dari uji koefisien determinasi (Adjusted $\mathrm{R}^{2}$ ) pada penelitian yang dilakukan dapat dilihat pada

${ }^{29}$ Seftianne dan Handayani, op. cit.

${ }^{30}$ Nabayu, Y. P., Marbun, N., \& dkk. (2020). Pengaruh Profitabilitas, Struktur Aktiva, dan Likuiditas terhadap Struktur Modal pada perusahaan makanan dan minuman yang terdaftar di Bursa Efek Indonesia pada tahun 2014-2017. Jurnal Paradigma Ekonomi, Vol.15,No.2, Hal.148.

31 Putri, R., \& Fadhlia, W. (2014). Pengaruh Struktur Aktiva Dan Tingkat Pertumbuhan Penjualan Terhadap Struktur Modal Perusahaan Manufaktur Yang Terdaftar Di Bursa Efek Indonesia. Jurnal Dinamika Akuntansi Dan Bisnis, Vol.1, No.2, Hal. 219.

${ }^{32}$ Affandi, op. cit.

33 Mulyani, H. S. (2017). Analisis Struktur Modal Berdasarkan Growth Opportunity, Profitabilitas, Effektive Tax Rate Dan Asset Tanggibility (Studi Pada Perusahaan Food and Beverage Yang Terdaftar Di Bursa Efek Indonesia Tahun 2011-2015). Jurnal Ilmiah Manajemen \& Akuntansi, Vol.4, No.2, Hal.57.

34 Tijow, A., Sabijono, H., \& Tirayoh, V. (2018). Pengaruh Struktur Aktiva Dan Profitabilitas Terhadap Pengaruh Struktur Aktiva Dan Profitabilitas Terhadap Pengaruh Struktur Aktiva Dan Profitabilitas Terhadap. Jurnal Riset Akuntansi Going Concern, Hal.486-487.

${ }^{35}$ Rubiyana dan Kristianti, op. cit. 
tabel R Square diperoleh nilai R Square sebesar 0,368. Hal ini menunjukkan variabel independent mempengaruhi variabel dependen sebesar 36,8\%, sedangkan $63,2 \%$ dipengaruhi oleh variabel lain di luar penelitian ini.

\section{Kesimpulan}

Berdasarkan hasil penelitian mengenai pengaruh Likuditas, Risiko Bisnis, Struktur Aktiva terhadap Struktur Modal (studi empiris pada perusahaan manfukatur sektor industri barang konsumsi yang terdaftar di Bursa Efek Indonesia (BEI) pada periode 2015 - 2019) dapat disimpulkan sebagai berikut :Variabel Likuiditas yang diukur dengan current ratio, berdasarkan hasil uji t menunjukan bahwa variabel likuiditas berpengaruh negatif signifikan terhadap struktur modal pada perusahaan manfukatur sektor industri barang konsumsi yang terdaftar di Bursa Efek Indonesia (BEI) pada periode 2015 - 2019. Variabel Risiko Bisnis yang diukur dengan BRISK, berdasarkan hasil uji $\mathrm{t}$ menunjukan bahwa variabel risiko bisnis tidak berpengaruh terhadap struktur modal pada perusahaan manfukatur sektor industri barang konsumsi yang terdaftar di Bursa Efek Indonesia (BEI) pada periode 2015 - 2019. Variabel Struktur Aktiva yang diukur dengan FAR, berdasarkan hasil uji t menunjukan bahwa variabel Struktur Aktiva tidak berpengaruh terhadap struktur modal pada perusahaan manfukatur sektor industri barang konsumsi yang terdaftar di Bursa Efek Indonesia (BEI) pada periode 2015 2019. Dan berdasarkan hasil uji simultan (F) menunjukan bahwa seluruh variabel independen berpengaruh secara simultan terhadap struktur modal pada perusahaan manfukatur sektor industri barang konsumsi yang terdaftar di Bursa Efek Indonesia (BEI) pada periode 2015 2019.

\section{Daftar Pustaka}

Affandi, R. D. (2016). Pengaruh Profitabilitas, Growth Opportunities, Likuiditas, Dan Tangibility Terhadap Struktur Modal Pada Perusahaan Sektor Infrastruktur, Utilitas, Dan Transportasi Yang Terdaftar Di Bursa Efek Indonesia Periode 2011-2014. Jurnal Ilmu Manajemen, Hal.174.

Brigham E.F.\& Houston J.F.(2011).Dasar-Dasar Manajemen Keuangan. Buku Ke 2, Edisi 11.

Cahyani, N. I., \& Handayani, N. (2017). Pengaruh Profitabilitas, Likuditas, Size, Kepemilikan Institusional, Dan Tangibility Terhadap Struktur Moda. Jurnal Ilmu dan Riset Akuntansi , Volume 6, Nomor 2, Hal. 617.

Deviani, M., \& Sudjarni, L. (2018). Pengaruh Tingkat Pertumbuhan, Struktur Aktiva, Profitabilitas,Dan Likuditas Terhadap Struktur Profitabilitas, Dan Likuiditas Terhadap Struktur. E-Jurnal Manajemen Unud, Vol. 7, No. 3, Hal. 1244- 1246.

Dewi, N., \& Badjra, I. (2014). Pengaruh Likuiditas, Profitabilitas, Tangibility Asset, Ukuran Perusahaan Dan Pajak Terhadap Asset, Ukuran Perusahaan Dan Pajak Terhadap. Ejurnal Manajemen, 3021.

Dewiningrat, A. I., \& Mustanda, I. (2018). Pengaruh Likuiditas, Profitabilitas, Pertumbuhan Penjualan, Dan Struktur Aset Terhadap Struktur Modal. E-Jurnal Manajemen Unud,, Vol. 7, Hal. 3476. 
Jurnal Al-Qardh, Vol. 6, No.1, Juli 2021, hlm. 30-44

Devi, N. N., Sulindawati, N. G., \& Wahyuni, M. (2017). Pengaruh Struktur Aktiva, Profitabilitas, Ukuran Perusahaan, Likuditas, dan Kepemilikan Manajerial Terhadap Struktur Modal Perusahaan (Studi empiris pada perusahaan manufaktur yang terdaftar di Bursa Efek Indonesia periode 2013-2015). e-journal S1.Ak Universitas Pendidikan Ganesha, Vol.7, N0.1, .

Hardanti, S., \& Gunawan, B. (2010). Pengaruh Size, Likuiditas, Profitabilitas, Risiko, Dan Pertumbuhan Penjualan Terhadap Struktur Modal (studi empiris pada perusahaan manufaktur di Bursa Efek Indonesia). Jurnal Akuntansi dan Investasi, Vol. 11 No. 2, Hal. 157 - 159.

Laksana, I., \& Widyawati, D. (2016). Pengaruh Kepemilikan Saham, Kebijakan Dividen, Tangibility, Size, Dan Profitabilitas Terhadap Struktur Modal. Jurnal Ilmu dan Riset Akuntansi, Volume 5, Nomor 4, Hal.9-10.

Lasut, S., Rate, P., \& Raintung, M. (2018). Pengaruh Ukuran Perusahaan, Profitabilitas, Dan Likuiditas Terhadap Struktur Modal Pada Perusahaan Otomotif Yang Terdaftar di Bursa Efek Indonesia Periode 2012-2015. Jurnal EMBA, Vol.6 No.1, Hal.14.

Liang , I., \& Natsir, K. (2019). Pengaruh Profitabilitas,Likuiditas, dan Ukuran Perusahaan Terhadap Struktur Modal. Jurnal Manajerial dan Kewirausahaan, Vol.1, No.3, Hal. 486-487.

Maryanti , E. (2016). Analisis Profitabilitas, Pertumbuhan Perusahaan, Pertumbuhan Penjualan Dan Struktur Aktiva Terhadap Struktur Modal Pada Perusahaan Sektor Industri Barang Konsumsi Yang Terdaftar di Bursa Efek Indonesia(Studi Empiris Pada Perusahaan Manufaktur yang Terdaf. Riset Akuntansi dan Keuangan Indonesia, , 1(2), Hal. 146.

Rubiyana, M., \& Kristanti. (2020). Pengaruh Profitabilitas, Struktur Aktiva, Pertumbuhan Perusahaan, Risiko Bisnis Dan Aktivitas Perusahaan Terhadap Struktur Modal. BALANCE : Economic, Business, Management, and Accounting Journal Vol. XVII No. 2 Bulan Juli Tahun 2020.

Mulyani, H. S. (2017). Analisis Struktur Modal Berdasarkan Growth Opportunity, Profitabilitas, Effektive Tax Rate Dan Asset Tanggibility (Studi Pada Perusahaan Food and Beverage Yang Terdaftar Di Bursa Efek Indonesia Tahun 2011-2015). Jurnal Ilmiah Manajemen \& Akuntansi, Vol.4, No.2, Hal.57.

Munandar, A., Pratiwi, A., \& Hasan, I. (2019). Pengaruh Risiko Bisnis Terhadap Struktur Modal Pada Perusahaan Pabrik Kertas PT. TJIWI KIMIA TBK PERIODE 2013-2018. Jurnal Manajemen dan Keuangan, Volume: 7 No: 2, Hal. 56.

Nabayu, Y. P., Marbun, N., \& dkk. (2020). Pengaruh Profitabilitas, Struktur Aktiva, dan Likuiditas terhadap Struktur Modal pada perusahaan makanan dan minuman yang terdaftar di Bursa Efek Indonesia pada tahun 2014-2017. Jurnal Paradigma Ekonomi, Vol.15,No.2, Hal.148.

Najmudin.(2011).Manajemen Keuangan Dan Aktualisasi Syar'iyyah Modern. Penerbit:C.V ANDI OFFSET. 
Natalia, D. X. (2020). Pengaruh Profitabilitas, Struktur Asset, Likuiditas, Dan Pajak Terhadap Struktur Modal (Studi Pada Perusahaan Konstruksi Bangunan Yang Terdaftar di BEI). jurnal ilmiah mahasiswa FEB, Vol.8, No.2.

Nengsih, W., \& Yanti. (2020). Pengaruh Profitabilitas, Resiko Bisnis, Likuditas, dan Tangibility terhadap Struktur Modal. Jurnal MultiParadigma Akuntansi Tarumanegara, Vol.2, No.1,Hal.90.

Nst, M. (2017). Pengaruh Likuiditas, Risiko Bisnis Dan Profitabilitas Terhadap Struktur Modal Pada Perusahaan Textile Dan Garment Yang Terdaftar Dan Garment Yang Terdaftar. Jurnal Riset Akuntansi \& Bisnis, Vol. 17 No. 2, Hal.1699.

Nurwandari, N., \& Hidayat, I. (2017). Pengaruh Profitabilitas Dan Risiko Bisnis Terhadap Struktur Modal Perusahaan Food And Beverage. Jurnal Ilmu dan Riset Manajemen, Volume 6, Nomor 6, Hal. 12.

Pradana, H., Fachrurrozie, \& Kiswanto. (2013). Pengaruh Risiko Bisnis, Struktur Aset, Ukuran Dan Pertumbuhan Penjualan Terhadap Strutur Modal. Accounting Analysis Journal, Hal.424.

Primantara, A., \& Dewi, M. (2016). Pengaruh Likuditas, Profitabilitas, Risiko Bisnis, Ukuran Perusahaan, dan Pajak Terhadap Struktur Modal. E-Jurnal Manajemen Unud, 26982699.

Putri, R. P., \& Andayani. (2018). Faktor-Faktor Yang Mempengaruhi Struktur Modal Perusahaan Manufaktur Di Bursa Efek Indonesia. Jurnal Ilmu dan Riset Akuntansi, Hal. 2.

Putri, R., \& Fadhlia, W. (2014). Pengaruh Struktur Aktiva Dan Tingkat Pertumbuhan Penjualan Terhadap Struktur Modal Perusahaan Manufaktur Yang Terdaftar Di Bursa Efek Indonesia. Jurnal Dinamika Akuntansi Dan Bisnis, Vol.1, No.2, Hal. 219.

Rubiyana, M., \& Kristanti, T. F. (2020). Pengaruh Profitabilitas, Struktur Aktiva, Pertumbuhan Perusahaan, Risiko Bisnis Dan Aktivitas Perusahaan Terhadap Struktur Modal. Economic, Business, Management, and Accounting Journal, Vol. XVII No. 2, Hal. 39.

Sari , S., Ramadhani, D., \& Yulia, Y. (2019). Pengaruh Risiko Bisnis, Struktur Aktiva, Ukuran Perusahaan, Dan Pertumbuhan Penjualan Terhadap Struktur Modal. Jurnal EKOBISTEK, Vol.8, No. 2, Hal.18.

Seftianne, \& Handayani, R. (2011). Faktor-Faktor Yang Mempengaruhi Strukur Modal Pada Perusahaan Publik Sektor Manufaktur. JURNAL BISNIS DAN AKUNTANSI, Vol.13, No,1, Hal.52.

Septiani, N., \& Suaryana, I. (2018). Pengaruh Profitabilitas, Ukuran Perusahaan, Struktur Aset, Risiko Bisnis dan Likuiditas pada Struktur Modal. E-Jurnal Akuntansi Universitas Udayana, Vol.22.3. Hal. 1648,1707.

Husnan Suad \& Pudjiastuti.(2012). Dasar - Dasar Manajemen Keuangan.Penerbit \& Percetakan:UPP STIM YKPN.Edisi ke enam. 
Jurnal Al-Qardh, Vol. 6, No.1, Juli 2021, hlm. 30-44

Tijow, A., Sabijono, H., \& Tirayoh, V. (2018). Pengaruh Struktur Aktiva Dan Profitabilitas Terhadap Pengaruh Struktur Aktiva Dan Profitabilitas Terhadap Pengaruh Struktur Aktiva Dan Profitabilitas Terhadap. Jurnal Riset Akuntansi Going Concern, Hal.486487.

Wairooy, M. (2019). Pengaruh Ukuran Perusahaan Dan Risiko Bisnis Terhadap Struktur Modal Pada Perusahaan Industri Otomotif Yang Terdaftar Di Bursa Efek Indonesia. jurnal ekonomi, 79-89.

Wardhana, I., \& Sudiartha, G. (2015). Pengaruh Likuiditas, Ukuran Perusahaan, Risiko Bisnis, dan Usia Perusahaan Terhadap Struktur Modal Pada Industri Pariwisata Di Bursa Efek Indonesia Periode 2010-2013. E-Jurnal Manajemen Unud, Vol.4, N0.6, Hal.1704.

Zulkarnain, M. (2020). Pengaruh likuiditas dan profitabilitas terhadap struktur modal. FORUM EKONOMI, Hal.52-54. 